\title{
Key Plant, Key Pests: Chinese Fringe (Loropetalum chinense) ${ }^{1}$
}

Juanita Popenoe, Caroline R. Warwick, and Jianjun Chen²

\section{Key Plant: Chinese Fringe (Loropetalum chinense)}

Loropetalums are native to eastern Asia, including China, Japan, and the Himalayas. Standard cultivars may grow up to 10 feet in height, but new dwarf selections are less than two feet, and are commonly used as groundcover or as landscape plants. Leaves vary in color, ranging from green to purple to burgundy, and flowers range from white to pink depending on the cultivar. They are commonly found in Florida landscapes, and can be found throughout the United States in USDA hardiness zones 7 through 10. It is important to select the right cultivar for the landscape application, as the stress of excessive pruning leads to early decline of the shrub in the landscape. Selective handpruning is much less stressful to the plant than shearing with electric- or gasoline-powered pruning shears. The plants grow best in part shade to part sun, have moderate drought tolerance, and are adapted to a wide range of soils. Loropetalum species do not do well with reclaimed water (Gilman 2014).

\section{Key Pests: Chinese Fringe}

This series of Key Plant, Key Pests publications are designed for Florida gardeners, horticulturalists, and landscape professionals to help identify common pests associated with common Florida flora. This publication, the fifth in the Key

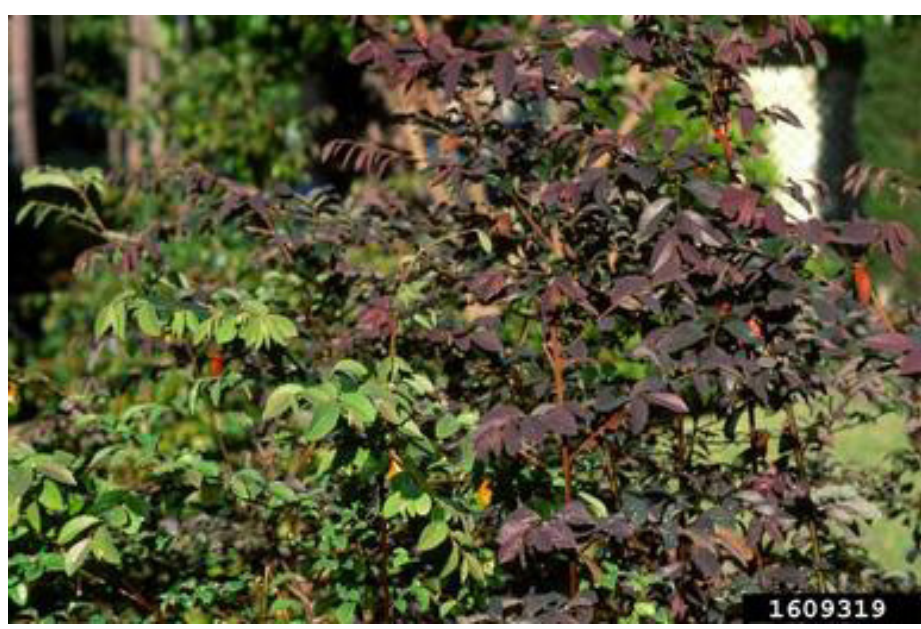

Figure 1. Chinese fringe cultivar selections may have leaves varying from green to purple to burgundy.

Credits: John Ruter, University of Georgia, bugwood.org

Plant, Key Pests series, helps identify the most common pests found on the Chinese fringe (Loropetalum chinense).

This publication provides information and general management recommendations for copper deficiency, Pseudocercospora, and olive gall. For a more comprehensive guide of woody ornamental insect management, download the current Professional Disease Management Guide for Ornamental Plants here or the Integrated Pest Management in the Commercial Ornamental Nursery Guide here.

1. This document is ENH1298, one of a series of the Environmental Horticulture Department, UF/IFAS Extension. Original publication date July 2018. Visit the EDIS website at http://edis.ifas.ufl.edu.

2. Juanita Popenoe, multi-county commercial fruit production agent IV; Caroline Roper Warwick, science communication specialist, and Jianjun Chen, professor; Mid-Florida Research and Education Center, UF/IFAS Extension, Apopka, FL 32703.

The Institute of Food and Agricultural Sciences (IFAS) is an Equal Opportunity Institution authorized to provide research, educational information and other services only to individuals and institutions that function with non-discrimination with respect to race, creed, color, religion, age, disability, sex, sexual orientation, marital status, national origin, political opinions or affiliations. For more information on obtaining other UF/IFAS Extension publications, contact your county's UF/IFAS Extension office. 


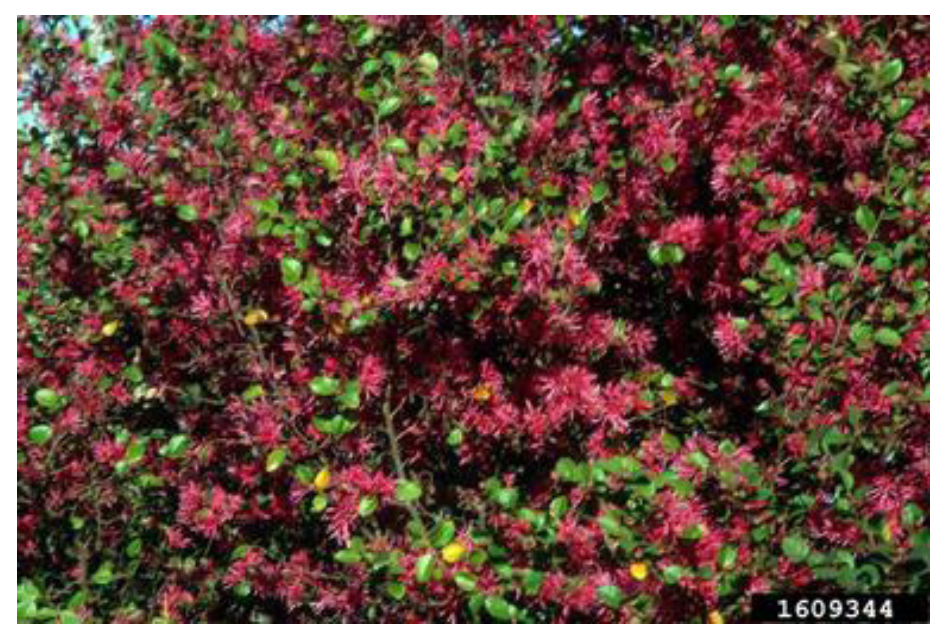

Figure 2. Chinese fringe blooms can range from pink (pictured) to white.

Credits: John Ruter, University of Georgia, bugwood.org

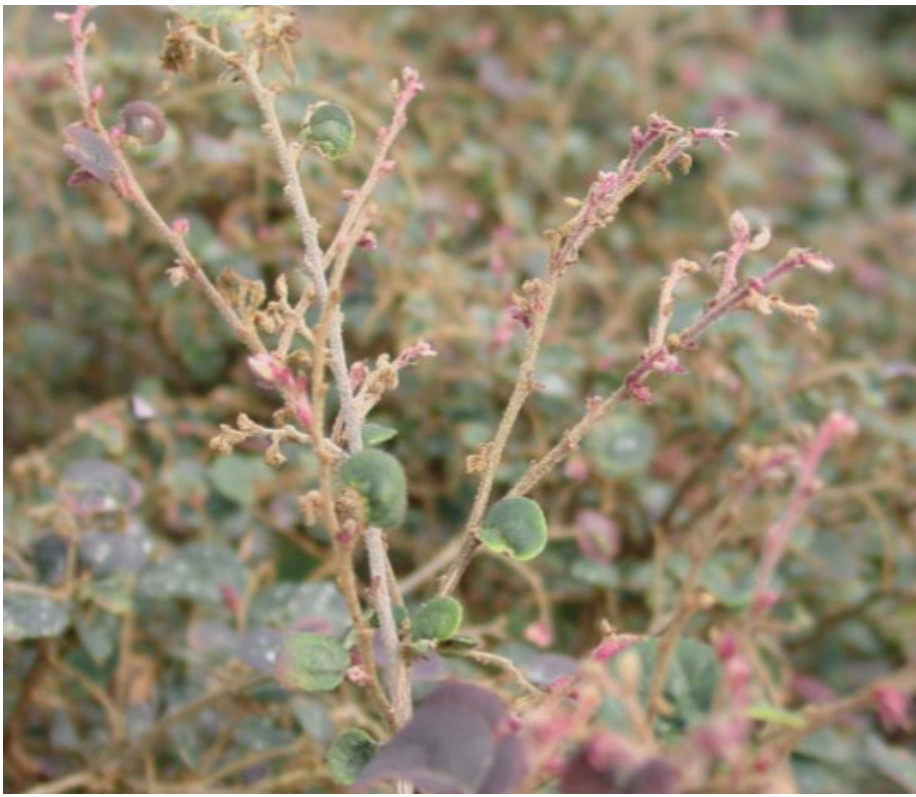

Figure 3. The effects of copper deficiency on Loropetalum leaves and new growth.

Credits: Juanita Popenoe, UF/IFAS

\section{Copper Deficiency}

Recognition: New growth is stunted, and new leaves are small, distorted, and can appear to be crumbled or dried out.

Contributing factors: The 'Ruby' cultivar is the most susceptible. Other cultivars do not seem to be as affected; however, they should be monitored for signs of deficiency, especially where soil $\mathrm{pH}$ is high. Soil $\mathrm{pH}$ can have a detrimental effect on plant growth, so for recurring problems, submit a soil sample at your local UF/IFAS Extension office.

Management recommendations: Foliar copper sprays can be used to provide copper to the plant. Many copper sprays

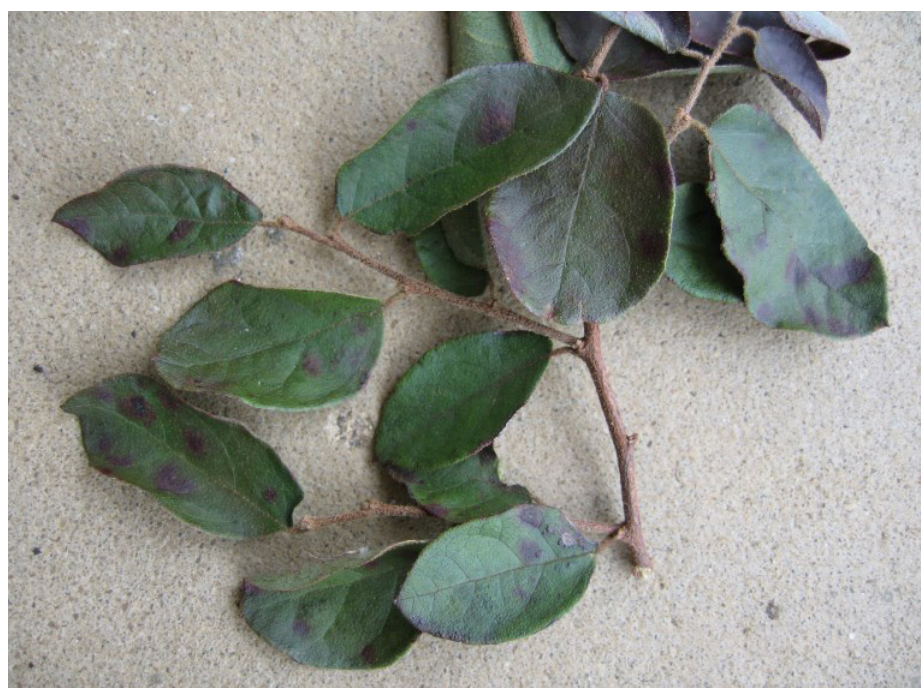

Figure 4. Loropetalum leaves showing signs of Pseudocercospora. Credits: Juanita Popenoe, UF/IFAS

are sold as fungicides. Copper fertilizers are also available as a supplement. When applying sprays, fungicides, or fertilizers, be sure to follow instructions provided on the label (Sewards and Shober 2014).

\section{Pseudocercospora}

Recognition: Dull purplish leaf spots appear on the leaves. This is the only reported leaf disease for Loropetalum at this time. It is not common.

Contributing factors: Cool, moist weather can encourage disease spread and development.

Management recommendations: Treat as for a Cercospora infection. Chemical control recommendations can be found in the Integrated Pest Management in the Commercial Ornamental Nursery Guide here (Mangandi and Peres 2015).

\section{Olive Gall (Pseudomonas savastanoi)}

Recognition: Dark-colored, rough-surfaced galls of varying sizes on shoots or stems. The gall will enlarge until a branch or stem is encircled, causing dieback of the affected branch.

Contributing factors: This bacterium may be spread on pruning equipment or through other wounds. Bacterial ooze from the galls during wet, cloudy weather may be splashed to other healthy shoots. Wetter environments have been reported to increase severity. Natural openings and wounds remain susceptible to infection for up to 14 days.

Management recommendations: Sanitation practices are the only current option for control. Maintenance of diseasefree blocks for cutting sources, disinfection of cutting 


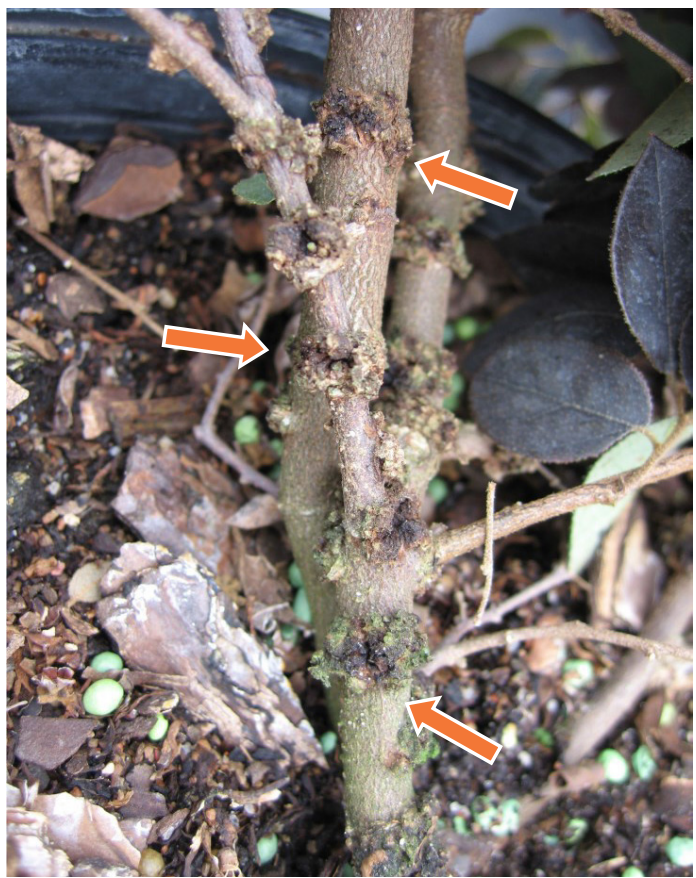

Figure 5. Loropetalum stems covered in Pseudomonas savastanoi galls. Credits: Juanita Popenoe, UF/IFAS

tools after each cut, and briefly dipping cuttings in a fresh dilute $(10 \% \mathrm{v} / \mathrm{v})$ bleach solution or similar bactericidal surface disinfectant for 10 seconds followed by a quick rinse in clean tap water will reduce surface contamination of cuttings. Weekly applications of a copper bactericide during rooting may help prevent infection but may slow root development and growth. Preventative applications of copper bactericides should be continued during extended periods of wet weather in the field. Discard symptomatic plants; there are no chemical treatments that will eradicate the causal bacterium on diseased plants. Removal of galled branches will only slow the spread (Bonkowski, Joseph and Bayo 2015).

\section{References}

Bonkowski, J., B. Joseph, and D. Bayo. "Pseudomonas savastanoi." https://wiki.bugwood.org/Pseudomonas_savastanoi

Gilman, E. F. 2014. Loropetalum chinensis Chinese Fringe Bush. FPS-355. Gainesville: University of Florida Institute of Food and Agricultural Sciences. http://edis.ifas.ufl.edu/ fp355

Mangandi, J. and N. A. Peres. 2015. Cercospora Leaf Spot of Rose. PP267. Gainesville: University of Florida Institute of Food and Agricultural Sciences. http://edis.ifas.ufl.edu/ pp267

Sewards, J. and A. L. Shober. 2014. Improving the Health of Declining Loropetalum in the Home Landscape. SL354.
Gainesville: University of Florida Institute of Food and Agricultural Sciences. http://edis.ifas.ufl.edu/ss556 